\title{
Etiek en menseregte
}

PROF. J. H. VAN WYK.

Voordat nader ingegaan word op die vrae rondom die teologiese grondslae van die begrip "menseregte" word enkele inleidende opmerkings gemaak wat vir die verdere betoog baie belangrik is.

\section{INLEIDING}

1.1. Wanneer cor menseregte besin word, moet baie duidelik teen 'n pragmatiese benadering gewaak word en vir 'n prinsipiële ontwerp gekies word. Uit die geskiedenis van hierdie aangeleentheid blyk o.a. dat juis bevoorregtes, d.w.s. hulle wat reeds oor die "regte" beskik, hulle tén die uitbreiding van menseregte verset het terwyl die ontregtes hulle ten gunste daarvan uitgespreek en hulle daarvoor beywer het.

1.2. Daar moet duidelik onderskei word tussen 'n liberale, marxis tiese en Christelike opvatting van menseregte. Selfs al sou daar op bepaalde punte ooreenstemming wees, dan nog bly daar groot verskille t.o.v. o.a. fundering, inkleding, middele en motivering. (W. H. Velema, $1980: 46$ ).

1.3. Wat die humanistiese benaderings tot menseregte betref, moet ook deeglik rekening gehou word met die "algemene openbaring" van God (vgl. Matt 5:45, Luk 16; 8, 2 Kor 10:5, Rom 2:14 e.v.). Selfs buite die kring van gelowiges bestaan daar vanweë die Here God se algemene goedheid 'n mate van kennis van goed en kwaad by die mens. "Humaniste en ateĩste kan soms sedelike insigte openbaar waarvan Christene - soms eers veel later - moet getuig dat dit ook volgens die norm van Gods geopenbaarde wet volkome juis is" (Jonker, 1984:56; vgl. Douma 1983:24 ev). Dit beteken nié dat hierdie algemeen gekonstateerde normbesef nou normatief moet wees nie (Velema, 1980:47). Normatief vir ons handelinge b!y steeds slegs die Woord van God.

1.4. Aansluitend by bg. twee punte moet steeds rekening gehou word met die saak waaroor dit gaan en die (dikwels omstrede) inkleding daarvan (Jonker, 1984: 49, 51). Dit is duidelik dat in nagenoeg alle vertoë t.o.v. menseregte dit gaan oor die saak van die "menswaardigheid van die mens", oor hoe die mens tot sy reg en volle ontplooiing kan kom.

1.5. Wat die Christelike benadering tot menseregte betref, gaan dit fundamenteel oor 'n Bybelse mensbeskouing (Velema, 1980:27, Du Toit, 1984:66 ev) en Bybelse Godsleer. En wat hierdie mensbeeld betref, spits dit veral toe op ' $n$ verklaring daarvan dat die mens geskape is "na die beeld van God". Uiteraard moet oor hierdie beeldskap dan gehandel word nié net vanuit 'n skeppingsperspektief nie, maar ook vanuit 'n Christologiese en pneumatologiese visie. 
1.6. Nagenoeg alle behoudende Gereformeerde etici het geen beswaar om die begrip menseregte te gebruik nie, solank daarmee nie aangeboire en inherente menseregte bedoe! word nie, maar wel (deur God) geskonke en verleende menseregte (Velema 1980:32, 45; Douma, 1983:20 - 21, 23, 26; Jonker, 1984:52-53; Du Toit, $1984: 66$; Heyns, 1982:389; J P de Vries, $1981: 133-136)$. Die Bybel weet nie van ' $n$ inherente waardigheid of natuurlike regtc wat die mens in homself besit, los van God en sy medemens, om nie. Maar dit beteken nie dat die mens geen regte besit nie. Hy besit, naas baie voorregte, ook inderdaad van Gód geskónkc régte wat hy in vryheid en verantwoordelikheid moet uitleef. In sy verhouding tot God besit die mens geen regte nie, maar slegs voorregte; in sy verhouding tot sy medemens besit hy egter Go:lgegewe regte. Trouens, die begrippe regte-voorregte cn p'igte-verantwoordelikhede lê so ineengestrengel dat hulle slegs tot groot skade van mekaar geisoleer kan word.

1.7. Die vraag na menseregte raak nie net die Bybelse mensbeskouing nie, maar ook die Bybe!se samelewingsbeskouing. Die mens bestaan immers nie atomisties op die wêreld nie, maar realiseer sy menswees in ' $n$ wye reeks van kleinere en grotere samelewingsverbande en lewensfere. Daarom is ' $n$ benadering van menseregte slegs vanuit die mensbeeld te eng, ò daar moet van hieruit ook aan die sosiale en strukturele dimensies van menswees aandag bestee word. Daar moet dus naas individuele regte ook oor sosiale regte gehandel word.

$\mathrm{Na}$ hierdie inleidende oefenlopie kan voorts aandag aan die teolo. giese grondslae van menseregte bestee word.

\section{ETIEK VAN MENSEREGTE}

Dit is duidelik dat die begrip menseregte nie in die Skrif voorkom nie en dat dit dus nie voor die hand lê om 'n reeks tekste ten gunste daarvan aan te voer nie. Veel eerder sal met die totale Bybelse boodskap rekening gehou moet word terwyl veral gefokus sal word op die Bybelse mensbeskouing, asook samelewingsvisie. Hoewel sommige hier huiwerig is om oor menseregte binne die kader van die Tien Gebooie te handel (Douma, 1983:28), is ander myns insiens tereg van oordeel dat dit wél moontlik en nodig is (Velema, $1980: 45$, Jonker, $1984: 55$ ).

Uiteraard word net breë riglyne aangestip.

\subsection{Bybelse mensbeskouing}

\subsubsection{Beeld-van-God-wees}

Die heel eerste en die heel belangrikste wat van enige mens gesê kan word is dat hy geskape is na die beeld van God (Gen 1:26). Sy geskapenheid dui op sy onselfgenoegsaamheid, afhanklikheid en onderworpenheid, en sy geskapenheid na die beeld van God wys op sy noue relasie met die lewende God (Berkouwer, 1957).

Die mens kan doodeenvoudig nie "op homself" beskou word nie, maar as religieus-geskape wese wys hy bo homself uit. Om godsdienstig te wees, is deel van sy menswees en wie hierdie basisrela. 
sie aantas, ontmenslik die mens. Die mens staan in 'n verbondsrelasie tot God.

Die mens het dus nie net die uitnemende voorreg en groot verantwoordelikheid om God te dien nie, maar ook die rég daartoe. Vryheid van erediens en godsdiens is ' $n$ deur God verleende menslike reg wat mense nie van mekaar wegneem nie. Die reg op die vryheid, die tyd en die wyse om God te dien, word in die eerste vier gebooie nader gereël. Tewens word in die vierde gebod ook die reg op rus en verandering uitgespel.

Beteken dit ook godsdiensvryheid vir hulle wat nie die ware God nie maar wel afgode dien? "Wie vryheid vra om God te dien, doen dit ook vir hulle wat hierdie vryheid misbruik vir die diens van afgode. Niemand kan deur wette of uiterlike magsmisdade verplig word om God te dien nie" (wat 'n saak van innerlike oortuiging is) (Velema, 1980:43). So bly daar ruimte om die evangelie van die koninkryk uit te dra en mense tot terugkeer na die lewende God op te roep.

Dit is waar dat die sondeval van die mens hierdie beeldwees radikaal aangetas het. Tog word die mens, ook die gevalle mens, deur God steeds behandel as beeld van God. Tewens, deur die verlossingswerk van Jesus Christus en die vernuwingswerk van die Heilige Gees word die weg na die herstel van die beeld geopen (Ef $4: 24$, Kol $3: 10$ ). Die (gelowige) mens moet gelykvormig word aan die beeld van Christus (Rom $8: 29$, Fil $3: 21$ ), wat immers die beeld van die onsienlike God is ( 2 Kor $4: 4$, Kol $1: 15)$.

\subsubsection{Medemenslik wees}

Dit is opvallend dat die Bybelse skeppingsverhaal die mens nie bloot as eenling teken nie - dit word trouens pertinent as "nie goed nie" omskryf (Gen 2:18) - maar juis as tweeheid, as medemenslikheid, as man en vrou (Gen $1: 27,2: 18$ ). Mens-wees is volgens die Bybel dus feitlik identies aan medemens-wees.

Van hierdie medemens-wees vorm die huwelik dan in 'n sekere sin die basisverhouding. Van hieruit neem dit talle gestaltes in die samelewing aan.

Juis omdat mens-wees so nou verbind is aan die medemens-wees het God sy gebooie gegee sodat hierdie medemenslikheid of naasteliefde konkrete vorm kan aanneem.

Die vyde gebod reël die reg op gesag en orde asook die eerbied en gehoorsaamheid aan gesagsdraers. Die sesde gebod reël die reg op lewe (en lewensruimte) en dus die onaantasbaarheid daarvan; menswaardigheid is ' $n$ gawe van God (vgl. Matt 6:26). (Dit impliseer al dadelik 'n kritiese instelling t.o.v. bv. algemene aborsie en eutanasie en 'n onregverdige oorlog.) Die sewende gebod reël die reg op huwelik, huwelikstrou en huweliksbeskerming en by implikasie ook huwelikskeuse. (Hiervolgens is die op Wet op verbod van gemengde huwelike $1949 / 1965$ en onbillike trekarbeid, wat die huwelikslewe ontwrig, moreel ongeoorloof.) Die agste gebod reël die reg op besittings en beskerming daarvan en by implikasie ook die reg op verwerwing en hantering daarvan. Die negende gebod 
reël die reg op 'n billike regspraak. En die tiende gebod reël die reg op beskerming teen verkeerde begeertes van ander mense. Saamgevat: die mens as beeld van God het reg op liefde! Dit is seker nie toevallig nie dat Christus in Mark 10:19 in die plek van die tiende gebod, of as samevatting van die laaste ses gebooie, aan die ryk jongman sê: "Jy mag nie iemand veronreg nie". Die liefde verbly hom nie oor onreg nie (1 Kor 13:6).

Hierdie regte is nie aangebore of van nature daar nie. Dit is nog minder regte teenoor God. Maar dit is regte wat God aan die mens verleen om waarlik menswaardig te kan lewe. Wie hierdie regte aantas, tas nie bloot "menseregte" aan nie, maar die ments as beeld van God en dus God self wat hierdie regte verleen het.

\subsubsection{Arbeider-wees}

Eintlik druk die begrip "arbeider-wees" nie voldoende uit wat hier ter sprake is nie. Hiermee saam moet cok aan anjer vegrippe, soos rentmeester-wees, heerser wees, bewerker-wees en bewaker-wees gedink word. Om die wêreld te bewerk en daaroor te heers (Gen $1: 28$, Ps 8), ja, om dit te bewerk en te bewaak (Gen 2:15), is immers van die vroegste opdragte wat die Here God aan die mens gegee het.

Werksaam-wees is deel van mens-wees (vgl. vierde gebod); wie nie werk nie, tas sy mens-wees aan (vgl. 2 Tess $3: 10$ ). Die mens het van Godsweë dus 'n rég op arbeid en op dit wat hiermee saamgaan: arbeidsgeleenthede, arbeidsvervulling en selfs arbeidsvreugde.

Onbillike werkreservering kom dus neer op 'n aantasting van 'n Godgegewe mensereg.

Voorts het die mens die reg op die gebruik van die natuurlike hulpbronne, maar nie op die misbruik daarvan nie. Hy moet die natuur ook oppas.

Nou verbonde aan die opdrag om te werk, is die hieruit voortvloeiende aspek van kultuurontplooiing met alles wat weer daarmee saamhang. Maar hieroor later meer.

\subsection{Bybelse samelewingsleer}

Uit bostaande het min of meer duidelik geword dat die mens nie as eenling leef nie, maar meesal in wyere verbande bestaan, wat ons samelewingsverbande kan noem. Hierdie verbande/strukture / sisteme het 'n groot invloed op ons mens-wees en ook hier kan sprake wees van reg en onreg. Nou weet ons dat die Bybel nie 'n volledig uitgewerkte samelewingsleer aan ons bied nie - dit is ook nie die doel van die Skrif nie - tog gee dit breë riglyne wat vir enige samelewing onmisbaar is en waarop ons kortliks die aandag wil vestig.

\subsubsection{Samelewingsverbande}

Ruimte ontbreek om hier aan elke afsonderlike samelewingsverband volledig aandag te gee. Daarom word die vernaamste verbande slegs kortliks vermeld ten einde meer aandag aan die samelewingsprinsipes te bestee.

Wanneer hier van samelewingsverbande gepraat word, word o.a. 
aan die volgende gedink: huwelik en gesin, volk en nasie, politiek en ekonomie, onderwys en akademie, mediese en regskring, tegniek en wetenskap, arbeid en ontspanning, kuns en kultuur, kontak- en kommunikasiemedia, nywerheid en industrie. Afgesien van die reeds genoemde (veral individuele) regte, geld ook in en t.o.v. hierdie samelewingsverbande sekere (meer sosiale) regte. Dit is nodig dat ons tans daaraan nader aandag gee.

\subsubsection{Samelewingsprinsipes}

Bykomend by wat reeds vermeld is, moet ten minste die volgende prinsipes (of "grondwaarhede", Velema, 1980:54 e.v.) eksplisiet vermeld word. Hierdie prinsipes is onmisbaar vir die strukturering van wat genoem word 'n "verantwoordelike samelewing" met die oog op diens aan die koninkryk van God.

\subsubsection{Ordelikheid en regverdigheid}

Alte seker het 'n mens die reg op 'n ordelike samelewing waar wet en orde heers en waar beskerming is. Die OT-iese koningskap lewer hiervan 'n bewys en in die NT is dit eweneens deel van die owerheidstaak, selfs in die geval van 'n nie-Christelike owerheid ( 1 Tim $2: 2$, Rom 13). "Wet en orde" moet egter steeds hand aan hand gaan met "reg en geregtigheid", waarsonder 'n vreedsame sa. melewing nie moontlik is nie (Jes $32: 17$, Ps $85: 11$, Jak $3: 18$ ). Elke mens het die reg om oral en altyd regverdig behandel te word.

Uiteraard ontvang die begrip geregtigheid in die Christelike etiek 'n ryker betekenis. Dit wys eerstens op die reg-maak van die mens se verbroke verhouding met God deur Jesus Christus (1 Kor 1:30).

Die herstel van hierdie basisverhouding tot God het egter konsekwensies vir die verhouding tot die naaste: ook dít moet régkom en rég wees (Matt $7: 12$, Rom $12: 18$ ). 'n Regverdige samelewing is duidelik 'n Bybelse ideaal (vgl. Amos 5:24, Spr 14:34). Geregtigheid word voorgehou as een van die kenmerke van die koninkryk van God (Rom 14:17) en as dié kenmerk van die beloofde nuwe wêreld ( 2 Pet $3: 13$ ). Juis hiertoe roep Christus sy navolgers op (Matt 5:20).

Prakties toegepas: 'n burger van 'n land het die reg tot 'n regverdige behandeling in die politiek (spreekreg, kiesreg, verkiesingsreg, bedingingsreg), in die ekonomie (gelyke betaling vir gelyke werk), in die regspraak (onpartydige verhoor), in die arbeid (gelyke geleenthede en meriete-bevordering), in die onderwys (gelyke onderrig), ens.

Veral moet in hierdie verband gewys word op die besondere sorg wat daar volgens Skrif aan die arme en ontregte en nooddruftige mens bestee moet word (vgl. Ps $82: 3-4$, Ps 107:41, Ps 146:7, Spr $14: 31,19: 17,28: 27$, Amos, Matt $25: 40$, Rom $12: 16$, Jak 1:27). Al sorg die Here God vir alle mense en op 'n besondere wyse vir sy kinders, gaan sy hart tog heel besonderlik uit tot hulle wat in nood is. En hierin moet ons Hom navolg. Armes en ontregtes het die reg om deur hul medemens regverdig en menswaardig behandel te word. 


\subsubsection{Vryheid en verantwoordelikheid}

Besit die mens ook 'n reg tot vryheid en verantwoordelikheid? Godsdiensvryheid, gewetensvryheid, persvryheid, kunsvryheid, politieke en ekonomiese vryheid, slawe-vryheid? Inderdaad, maar weer eens, in die Christelike etiek ontvang hierdie aspekte 'n Skriftuurlike fundering en motivering. In die Christelike etiek is bevryding / verlossing fundamenteel 'n saak van Gód: Hý bevry sy volk uit Egiptiese afgodediens en slawerny, Hý lei hulle terug uit Babiloniese ballingskap, Hý verlos deur Jesus Christus. Hierna roep Hy sy volk op om, bevry van die sonde, ook bevry-tot-verantwoordelikheid te gaan leef. Die mens moet antwoord op die bevryding deur God in Christus en só verantwoordelik lewe en 'n "verantwoordelike samelewing" opbou.

Ons moet hier, anders as by sekere vorme van die Teologie van die Rewolusie/Bevryding, onderskei tussen heil en heiliging, hoewel ons die twee nie mag skei nie (vgl. Velema, 1980:57-59). Christus maak ons vry (Hy skenk heil), maar "sy bevryding roep tot die erkenning van menseregte" (Hy vra heiliging) (Velema, 1980:57).

Die mens word dus vrygemaak tot 'n verantwoordelike bestaan. Hierdie verantwoordelike vryheid en vrye verantwoordelikheid moet sy neerslag in die volle samelewing vind. Dit is voorregte van God wat t.o.v. die medemens 'n rég is.

\subsubsection{Gebrokenheid en heelheid}

Wanneer oor "gebrokenheid en heelheid" - mens sou dit ook "sonde en versoening" kon noem - gehandel word, word 'n ietwat ander aspek aangesny. Gebrokenheid kan tog nie 'n rég wees nie, daarvoor druis dit te dirck in teen die oorspronklike bedoeling van die Here met die mens. Wel is dit 'n feitlikheid wat die ganse samelewing voortdurend ontwrig en in verskillende gestaltes aan die lig tree: ongelykwaardigheid, on regverdigheid, wettelcosheid, onderdrukking, mishandeling, vrees, vyandskap. konflik, polarisasie, ens. Orals waarop die mens sy hande lê: die organisasies wat hy vorm, die sisteme wat hy skep, die strukture wat hy bou, selfs die wette wat hy maak, is die vingermerke van die sonde te sien. Wette kan dus so geformuleer en so toegepas word dat dit die een groep bo die ander bevoordeel en dus "strukturele geweld" word.

Die aspek van gebrokenheid en sonde mag egter nooit as verskoning aangevoer word waarom daar in die sonde berus kan word nie. Dit word ter sprake gebring juis om bestry en oorwin te word. Die mens en die samelewing en die wêreld is nie bedoel om gebroke te wees nie. maar is op heelheid en harmonie, vrede en versoening aangelê. Dit is 'n voorreg wat God aan die mens skenk en 'n reg t.o.v. sy medemens. Die mens het ' $n$ reg om in vrede te leef.

In die Christelike etiek kom hierdie aspek in 'n totaal nuwe lig te staan. Dit is slegs Christus wat die sonde én alle bose magte oorwin het (Ef $4: 8$, Kol $2 ; 15$ ) en dit is slegs in verbondenheid aan Hom as Heiland dat die lewe weer héél word. Maar so 'n geheelde mens in Christus sal oral in die samelewing helend en versoenend optree, sover moontlik in vrede leef met álle mense (Rom $12: 18$, 
Heb $12: 14$ ) en sover moontlik aan álmal goed doen (Gal 6:10). Hy sal vrees en vyandskap beveg en liefde en vrede bevorder.

\subsubsection{Samelewing-transformasie}

Ons het reeds hierbo na die aspek van gebrokenheid en sonde verwys en juis dít bring mee dat elke samelewing en die totale wêreldsamelewing aan voortdurende verandering, hervorming en transformasie onderworpe behoort te wees. Stagnasie bied geleentheid aan die sonde en verkeerde om vas te roes. Daar is nie net ' $n$ plig tot reformasie nie, maar ook 'n reg. Wie 'n reformasie onmoontlik maak, roep 'n rewolusie op (vgl. Douma, 1983:24). Die groot vraag hier is egter watter middele in so 'n transformasieproses menswaardig en moreel geoorloof is. Het elke mens die reg om énige middel aan te wend of moet hulle wat vir menseregte ywer juis ook in die proses van transformasie menseregte eerbiedig? Is dit geoorloof om in ' $n$ vryheidstryd alle menseregte onder die voete te vertrap (vgl. Velema, 1980:53) en bv. onskuldiges op nie-diskriminerende wyse om die lewe te bring? Is tydens "rewolusionêre geweld" alles geoorloof wat teen "strukturele geweld" gemik is? Hoe sal dit moontlik wees om die lewe weer te normaliseer in die na-rewolusionêre fase as týdens die rewolusie alles geoorloof is? My konklusie is dat wie dit vir menseregte opneem, menswaardigheid sowel voor as tydens die transformasie moet eerbiedig.

\section{PRAKTIESE IMPLEMENTERING}

Die Gereformeerde Ekumeniese Sinode van Chicago 1984 het belangrike besluite oor menseregte vanuit Bybelse perspektief geneem. Die rapport wat hieroor gehandel het, het ten slotte op twaalf praktiese aspekte toegespits wat hieronder aangehaal word. Ten opsigte van hierdie rapport het die Nasionale Sinode van die GKSA te Potchefstroom 1985 myns insiens tereg besluit "dat dit ' $n$ unieke en waardevolle bydrae vanuit 'n suiwer Gereformeerde gesigspunt... bevat." Daarom haal ek ten slotte hierdie besluit aan as nadere konkretisering van wat hierbo aangevoer is:

' 1 . the right to life - challenging us to rise up unitedly in righteous indignation at the wanton slaughter of millions of unborn human beings, to counteract the ruthless killing of countless innocent people in many lands, and to work fervently for justice and peace in the face of the enormous life-threatening potentials of modern warfare; 2. the right to basic life needs - challenging us to share our food more generously with the poor and needy, the malnourished and starving peoples of the world, and to devise effective ways of distributing more equitably other basic good gifts of God's creation, such as clothing, shelter, energy, and health care;

3 . the rights of marriage and family life - challenging us to remove unbiblical obstacles to freedom of choice in marriage partners and to combat societal systems which permit the capricious invasion of the intimacy of family life and the forceful disappearance of family members;

4. the right to freedom of worship - challenging us to intervene 
on behalf of persecuted worshiping communities, Christians and others, assuring them the opportunity to gather in their places of worship without molestation, discrimination, or reprisal;

5. the right to religious liberty - challenging us in a religiously pluralist world to plead the cause of all persons and communities to freely choose and change their religions, to live out their beliefs freely, both privately and publicly, within the various structures of society, without infringing upon the similar rights of others;

6. the right to work - challenging us to a reformation of economic systems which exploit some at the expense of others, of working conditions which disrupt people's lives, deprive them of meaningful employment, and withhold from them a fair return upon their labors;

7. the right to freedom of association (including the right of nonassociation ) - challenging us to encourage societal conditions which make possible a life-enriching diversity of voluntary associations in which people, in keeping with their respective beliefs, can organize for the achievement of legitimate goals and purposes, whether cultural, social, economic, political, educational, scientific, recreational, or other; and which protect the rights of labor unions, as voluntary associations of workers, to promote stewardly enterprises;

8. the right of all citizens to participate responsibly in the political processes of the nation - challenging us to promote societal structures which allow all citizens, in harmony with their respective beliefs, equitable representation and participation in the crucial decision-making processes of the nation and which safeguard the basic rights of self-determination equitably for all groups in society;

9. the right to freedom of choice in education - challenging us to defend the prior right of the home to choose the kind of schools its children shall attend, without unjust penalties attached to such choices, so that all school systems, of whatever religion or phi'osophy, shall have equal standing with the government under the constitutional law of the land;

10. the right to freedom from all forms of discrimination - challenging us to advocate human rights for all, without distinctions based on race, color, ethnic origin, religion, sex, language, social status, political conviction, wealth, or property;

11. the right to an evenhanded administration of public justice challenging us to help shape a legal order which grants to all people equal treatment before the law and free access to the courts for redress of wrongs, with the assurance that no persons shall be subject to cruel, inhuman, and degrading punishment, arbitrary detention, imprisonment without fair trial, or unlawful restriction of liberty;

12. the right to a fair share in the rich resources of creation challenging us, while developing the resources of creation and protecting them against exploitation and pollution, to curtail consumptive greed and eliminate the abject poverty of needy neighbors the world over". (RES, 1983, 151 - 152.) 


\section{LITERATUUR}

Naas die literatuur wat in die onderstaande werk van Velema aangehaal is, kan op die volgende gewys word:

Berkouwer. G C 1957. De Mens het Beeld Gods. Kampen: J H Kok.

De Vries, J P. 1981. Vastheid en Vaart: Ethisch commentaar op actuele ont wikkelingen in kerk en politiek. Kampen: J H Kok (119-136).

Douma, J 1983. Christelijke Ethiek IV. Kampen: Van den Berg (4-32).

Du Plessis L M Junie 1986 ev. Perspektief op 'n menseregte-handves vir die RSA. Woord en Daad, 26 (296) : $15-17$.

Du Toit, D A (red) 1984. Menseregte. Kaapstad: Tafelberg

Evans, R A + A F 1983. Human Rights: A dialogue between the first and third worlds. Orbis.

GKSA. 1985. Acta $(628-637,651)$.

Greidanus, S. April 1984. Human rights in biblical perspective Calvin Theological Journal 19(1):5-31.

Handbuch der christlichen Ethik 3: Wege ethischer Praxis. Basel: Herder Freiburg, 1982, $197 \mathrm{ev.}$

Helberg, J L. Desember 1984. Die Ou Testament oor menseregte. In die Skriflig, 18(72) : 4 --12.

Heyns, J A. 1982. Teologiese Etiek I. Pretoria: NG Kerkboekhandel (388401).

Hofmeyer, J W. Desember 1981. Human rights and the new constitution: The church's responsibility. Theologia Evangelica 14(3) $61 \cdot 64$

Jonker, W D. 1984. Christelike geloof en menseregte. (In: Du Toit, D A (red). Menseregte, Kaapstad: Tafelberg).

Kik, Aad. Geloof in Menserechten. Kampen: J H Kok.

Raath. A W G. 11 Desember 1985. Die Calvinis en die erkenning van menseregte. Die Kerkbode (bl 7 ).

RES. Tertimony on Human Rights. 1983. Grand Rapids.

Schwartländer, J. 1979. Menschenrechte - ein Herausforderung der Kirche. München: Kaiser Verlag.

Stoker, H G. 1976 Oorsprong en Rigting I. Kaapstad: Tafelberg (113-123).

Van der Vyver, J D. 1977. Die juridiese faset van geregtigheid in die SuidAfrikaanse samelewing (In Geregtigheid in die Suid-Afrikaanse Samelewing. Potchefstroom: PU vir CHO, 58-82).

Van der Vyver, J D. 1974. Menseregte. Potchefstroom: IBC.

Van der Walt, S P. 1982. 'n Bladsy uit die eksistensiële etiek. Potchefstroom. Van der Westhuizen, H G. Die Bybelse basis vir menseregte. Hervormde Teologiese Studies, jg 34(1+2):88-96.

Velema, W H. 1980. Discussie over mensenrechten. Apeldoorn: Willem De Zwijgerstichting. 